\title{
ВІДКРИТІСТЬ ІНФОРМАЦІЙНОГО ПРОСТОРУ ТА КОНТРОЛЬ ЗА ДОСТУПНІСТЮ ІНФОРМАЦІЇ
}

Актуальність теми дослідження. Завдяки глобальній комп'ютеризації, телефонізації, Інтернету у розвинених країнах кожен громадянин може внести пропозиції, висловити оцінки, застереження, інфоомація стає доступною нині кожному членові суспільства.

Постановка проблеми. Слід звернути увагу на громадянське суспільство яке спирається на основні постулати, а саме, свободу висловлювань та інформації на основі верховенства права і поваги до прав людини.

Аналіз останніх досліджень і публікацій. Питання ролі інформаційного середовища у становленні громадянського суспільства розглядають О. Антіпова, Н. Войцих, В. Головій, С. Мошковська, Н. Петрова, А. Ракітов, В. Якубенко тощо.

Виділення недосліджених частин загальної проблеми. Автор акцентує увагу на головній та центральній проблемі розвитку інформаційної сфери, щодо забезпечення права на вільне отримання та обмін інформацією.

Постановка завдання. Розглядається інформаційний простір, його відкритість, контроль за доступністю інформації.

Виклад основного матеріалу. Найбільшим досягненням інформаційного суспільства є те, що завдяки створенню нового інформаційно-технологічного середовища, інформація миттєво долає відстані, які для неї практично зникають. Слід звернути увагу на суперечності, які розгортаються в суспільстві на тлі цих процесів. Це потребує клопіткої праці та пошуку законодавчих відповідних механізмів, а також унеможливлення тиску з боку фрінансових кланів та владних структур на засоби масової інфрормації. Це питання вирішиться, завдяки фрормуванню демократичних засад суспільної свідомості та принципам судового розгляду всіх конфліктних питань.

Висновки. Дослідник робить висновок про стан національного медіа-ринку з яким пов'язані питання розвитку інфрормаційної сфери, що потребує якісних змін, а саме, змістових, правових, управлінських, технологічних.

Ключові слова: людина; культура; інформація; безпека.

K. V. Zakharenko, Candidate of Philosophical Sciences

\section{INFORMATION SPACE TRANSPARENCY AND CONTROL OVER INFORMATION ACCESSIBILITY}

Urgency of the research. Thanks to global computerization, telephonisation, the Internet in developed countries, every citizen can make suggestions, express evaluations, cautions. information is now available to every member of society.

Target setting. The civil society is built on the basic postulates, namely freedom of expression and information, which is based on the rule of law and respect for human rights requires studying.

Actual scientific researches and issues analysis. Issues on the role of the information environment in the formation of civil society were studied by O. Antipova, N. Voitsykh, V. Holovii, S. Moshkovska, N. Petrova, A. Rakitov, V. Yakubenko et al.

Uninvestigated parts of general matters defining. The author focuses on the main and central problem of the information sphere development concerning the provision of the right for free access and information exchange.

The research objective. Consider the information space, its transparency, control over the information availability.

The statement of basic materials. The greatest achievement of the information society the creation of a new information and technological environment, where information instantly overcomes the distances that virtually disappear for it. It is necessary to draw attention to the contradictions that unfold against these processes in society. This requires an intensive work and a search for appropriate legislative mechanisms, as well as the pressure reduction from the side of financial clans and govern- 
ment structures on the media. This issue will be solved due to the formation of democratic foundations of public consciousness and the principles of judicial consideration of all conflict issues.

Conclusions. The researcher concludes about the state of the national media market, which involves issues of the information sphere development requiring qualitative changes, namely content, legal, managerial, technological.

Keywords: person; culture, information; safety.

DOI: 10.25140/2412-1185-2018-2(12)-30-35

Актуальність теми дослідження. В основі розв'язання проблеми забезпечення сталого розвитку інформаційного суспільства лежить низка питань, які потребують визначення чіткої методології правової підтримки порядку інформаційних відносин усіх учасників суспільства. Уявляється, що такий підхід повинен передбачати й відповідь на запитання про те, як зв'язати інституції (структури) громадянського суспільства, з одного боку, і забезпечити кожного громадянина суспільства визначеними повною мірою (конституційно), правами й обов'язками в інформаційній сфрері, зокрема правом громадян на отримання потрібної їм інформації. За таких умов розширення застосування в суспільстві інформаційно-комунікаційних технологій стає одним із ключових чинників у процесі трансформації суспільства у відкрите, а сама проблематика інформаційно-комунікаційних технологій має значний політичний і економічний резонанс [1].

Постановка проблеми. Слід звернути увагу на громадянське суспільство яке спирається на основні постулати, а саме, свободу висловлювань та інфрормації на основі верховенства права і поваги до прав людини.

Аналіз останніх досліджень і публікацій. Питання ролі інфоормаційного середовища у становленні громадянського суспільства викликають значний інтерес дослідників. Філософськоаксіологічні проблеми свободи слова в українському інформаційному просторі розглядають О. Антіпова, А. Ракітов. В. Головій та Н. Войцих визначають механізми взаємодії влади та $3 \mathrm{MI}$ в контексті становлення громадянського суспільства в Україні. Передумови входження України у глобальний інформаційний простір в контексті вимог міжнародної інформаційної безпеки аналізують аналізують С. Мошковська, Н. Петрова, В. Якубенко та інші.

Виділення недосліджених частин загальної проблеми. Слід дослідити інформаційну сферу, що забезпечує право на вільне отримання та обмін інформацією, та є головним чинником становлення громадянського суспільства.

Постановка завдання. Розглянути інфрормаційний простір, ступінь його відкритості, контролю за доступністю інформації.

Виклад основного матеріалу. Свобода у відкритому суспільстві передбачає наявність можливості вільного масового поширення інформації, яке $\epsilon$ ефрективним засобом захисту прав і свобод людини, фрормування громадської думки, реального впливу на суспільство й державну владу. Для теоретика свободи преси Дж. Мілля ще в середині XIX ст. було беззаперечним те, що «свобода друку є однією із необхідних гарантій проти урядових репресій та утисків» [2]. Демократія і свобода слова, свобода слова і свобода преси - ті неподільні цінності, якими вимірюється система свободи кожної держави. Утвердженню європейських стандартів права доступу до інфрормації передували виникнення і розвиток ідей такого права на рівні національних правових систем окремих європейських держав. Свобода висловлювань та інформації на основі верховенства права і поваги до прав людини є основними постулатами побудов громадянського суспільства, утвердженню справжньої демократії.

Забезпечення громадян суспільства широким і вільним доступом до отримання інфоормації, її використання та обміну нею $є$ найважливішою соціальною передумовою успішного розвитку сучасного інформаційного суспільства. Так, М. Моісеєв зазначає, що «вільний доступ до інформації, без якого немає сенсу вести мову про інформаційне суспільство, - найскладніша соціальнополітична проблема» [3]. Власне наявність знань, інформації для подальшої успішної еволюції й функціонування інфрормаційного суспільства ще недостатньо. Необхідне створення умов для того, щоб члени суспільства мали вільний доступ до якісної інформації й можливість ії використання у своїй практичній діяльності [4].

Вільний доступ усіх членів суспільства до інфрормації - провідна, характерна риса інфоормаційного суспільства. У зв'язку із цим, А. Ракітов справедливо вважає найголовнішою ознакою 
інформаційного суспільства ту обставину, що «будь-який індивід, група осіб, підприємство або організація в будь-якому місці країни й у будь-який час можуть одержати за відповідну плату або безкоштовно на основі автоматизованого доступу й систем зв'язку будь-які інформацію й знання, необхідні для їхньої життєдіяльності й рішення особистих і соціально значимих завдань» [5]. Така думка передбачає вироблення певної стратегії діяльності держави в цьому напрямі та докорінну зміну умов життєдіяльності людини та суспільства загалом.

Досвід західних країн свідчить, що ефективне функціонування незалежних мас-медіа $є$ необхідною умовою розбудови демократичного суспільства. За допомогою вільних та мінімально заангажованих засобів масової комунікації досягається відкритість як політичної системи, так і органів державної влади. Якщо в розвинених демократіях мас-медіа $€$ повноцінним, рівноправним суб'єктом політики, то у перехідних суспільствах, на зразок українського, їх місце та роль змінюються відповідно до логіки політичних процесів.

Становлення українських засобів масової інфрормації як потужного інституту сучасного суспільства відбувалося одночасно і разом зі становленням незалежності України. Дослідники переконані, що демократичному, правовому суспільстві, побудова якого декларується в Конституції України, засоби масової інформації, їх незалежність, свобода відіграють одну з провідних ролей у функціонуванні громадянського суспільства та владних інститутів. Подекуди вплив незалежних засобів інформації є потужнішим, аніж діяльність політичних партій та громадських об'єднань [6]. Тоді як сьогодні в Україні центральною проблемою розвитку інформаційної сфери є забезпечення права на вільне отримання й обмін інформацією. Воно потребує не політичних декларацій, а клопіткої роботи та пошуку відповідних законодавчих механізмів, унеможливлення тиску на засоби масової інформації з боку владних структур та фрінансових кланів. Завдання складне, але його можна виконати, спираючись на принципи обов'язково судового розгляду всіх конфоліктних питань і формування демократичних засад суспільної свідомості. Усі питання розвитку інформаційної сфрери тісно пов'язані зі станом національного медіа-ринку, який потребує якісних змін: технологічних, змістових, управлінських і в не осатаню чергу правових.

Щодо нашого законодавства в інформаційно-комунікативній галузі, то воно в основному відповідає загальноприйнятим міжнародним правовим стандартам, конвенціям з прав людини. Так, Конституція України повністю забезпечує виконання параграф 1 статті 10 Європейської Конвенції про права людини визначає, що «Кожен має право на свободу самовираження. Це право включає свободу мати свою думку, отримувати і поширювати інформацію та ідеї без втручання з боку властей та незалежно від кордонів». Гарантії доступу до інформації та її поширення теж аналогічно сформульовані у п. 2 ст. 19 Міжнародного пакту про громадські та політичні права від 1966 року [7].

Українське законодавство про засоби масової інформації та інформаційний простір включає в себе значну кількість нормативних документів. Серед них закони України «Про інфрормацію», «Про друковані засоби масової інформації (пресу) в Україні», «Про телебачення і радіомовлення», «Про авторське право і суміжні права», «Про інформаційні агентства», «Про рекламу», «Про державну таємницю», «Про внесення змін і доповнень до положення законодавчих актів України, що стосуються захисту честі, гідності та ділової репутації громадян і організацій», «Про зв'язок», «Про Національну раду України з питань телебачення і радіомовлення», «Про державну підтримку засобів масової інформації та соціальний захист журналістів», «Про порядок висвітлення діяльності органів державної влади та органів місцевого самоврядування в Україні засобами масової інформації», «Про видавничу справу», «Про систему Суспільного телебачення і радіомовлення України» та ін. Крім законів, функціонування та розвиток українських 3МІ визначають відповідні акти Президента України, постанови Верховної Ради, Кабінету Міністрів та інші нормативні документи владних структур і галузевих відомств. Утім, це ще не гарантує реального захисту інтересів суспільства щодо отримання вільної та неупередженої інформації.

Чинне законодавство, наприклад, залишило відкритим легальні шляхи до необмеженої концентрації в руках окремих юридичних або фрізичних осіб друкованих засобів масової інформації, усіх різновидів електронних засобів масової інформації. Воно без будь-яких обмежень дозволяє засновувати засоби масової інфрормації в нашій державі особам без громадянства та громадянам інших країн.

Зарубіжні засоби масової інфрормації мають кращі умови для фрункціонування в Україні, аніж власно українські. Вони виробляють в Україні свою продукцію й ухиляються від сплати мита та податків, проводять демпінгову політику, відбираючи у покупців і передплатників рекламу. Зокре- 
ма, щодня в Україну через прозорі кордони Росії завозяться величезні тиражі російських видань. Внаслідок цього Держбюджет недоотримує значні кошти, порушується чинне законодавство України, ігноруються інтереси національного виробника, а співвідношення українськомовних і російськомовних видань змінюється на користь останніх, тобто наших 20\% і 80\% - російськомовних. Крім того, в Україні видається 0,4 книжки на одну людину, у Росії - 3,2, у Польщі - 12,5, Німеччині - 19.

Сьогодні в Києві кількість годин радіомовлення на добу становить 380. I тільки 64 - державною мовою. В Україні зареєстровано періодичних друкованих видань українською мовою трохи більше ніж 2,5 тисячі. Решта - близько 8 тисяч - російські або двомовні.

Крім того задеклароване право щодо незалежності засобів масової інформації від владних структур носить суто популістський характер. Повною мірою це стосується місцевої преси. Як справедливо зазначає М. Яковенко, з одного боку, щодо цих мас-медіа імпонує ідея закону про повне відмежування преси від органів державної влади та органів місцевого самоврядування. 3 іншого, у демократично і економічно нерозвинутих країнах така преса миттєво перетворюється на залежну від грошових мішків або ж перетворюється на рекламно-еротичні видання 3 набором сумнівних сенсацій. І тоді стає неможливим виконання засобами масової інформації таких ії̈ головних функцій, як інформаційної, просвітницької, культурологічної тощо [8].

Незалежними від місцевих бюджетів засоби масової інформації можуть стати лише за умов, коли зможуть самоокуповуватися й існувати за рахунок надходжень від реклами та передплати. На даному ж етапі необхідно забезпечити невтручання владних структур у творчі процеси, пільгове кредитування, інші економічні важелі щодо налагодження вітчизняного газетного виробництва.

Нагальним питанням також є оптимізація структури власності суб'єктів інформаційної діяльності, якнайшвидший розвиток суспільного сектора, особливо в галузі електронних мас-медіа.

Створення організаційно-правової бази цих змін - ще одне нагальне завдання всіх гілок української влади. Крім цього, забезпечення інформаційної безпеки України і захист національного медіа-ринку вимагає перегляду основних принципів регулятивної політики на засадах інформаційної відкритості й підтримки власних медіа-виробників. Головним об'єктом такої підтримки має стати український зміст інформаційної продукції.

Державна політика забезпечення інформаційної безпеки повинна бути відкритою і передбачати інформування суспільства про діяльність державних органів і суспільних інститутів у сфері інформаційної безпеки з урахуванням обмежень, встановлених чинним законодавством України. Вона має виходити з принципу безумовної правової рівності всіх суб'єктів інформаційних відносин незалежно від їхнього політичного, соціального та економічного статусу, ґрунтуватися на обов'язковому забезпеченні прав громадян і організацій на вільне створення, пошук, отримання, накопичення, зберігання, перетворення і поширення інформації у будь-який законний спосіб.

Державна політика у сфері суспільно-інформаційних відносин повинна спрямовуватися на забезпечення права на достовірну, повну та своєчасну інформацію, свободу слова та інформаційної діяльності в національному інформаційному просторі України. Так, на думку Н. Войцих «Для становлення демократичного суспільства важливим є недопущення втручання будь-кого у зміст та внутрішню організацію інформаційних процесів, крім випадків, визначених законом відповідно до Конституції України» [9].

Сьогодні найбільш гострою проблемою в Україні $є$ відсутність у переважної більшості громадян довіри до державної влади, впевненості в тому, що всі гілки і структури влади, всі її посадові особи працюють в інтересах суспільства, а не в інтересах самої влади або своїх особистих. Тому вістря державної інформаційної політики має бути, перш за все, спрямоване на усунення «десріциту довіри до влади», який перешкоджає просуванню по шляху реформ.

У цьому сенсі ключовим завданням $€$ створення відкритого інформаційного середовища, включаючи забезпечення інформаційної прозорості державної влади, необхідної для формування громадянського суспільства і досягнення взаємодії між суспільством і владою на принципах довіри, взаєморозуміння та ділового партнерства.

Збалансоване функціонування системи інформаційної безпеки забезпечується за рахунок постійного обміну інформаційними потоками як усередині держави, так і між державами. Мошковська С. І. зазначає: «Будь-яка держава є відкритою системою, яка задіяна в кругообігу інформації. І якщо не буде відбуватися природний обмін в інформаційному просторі, то система руйнується» [10]. Завдання політики на інформаційному рівні керування процесом обміну. Останній не є хаоти- 
чним і підпорядковується цілком визначеним законам, один з яких можна сформулювати таким чином: інформація не викидається в інформаційний простір довільним способом, а посилається передусім туди, де вона необхідна і її здатні сприйняти [11].

Для створення відкритого інформаційного простору в Україні, перш за все, необхідно запустити механізм практичної реалізації конституційного права на свободу одержання інформації. Правовою основою такого механізму повинні стати законодавчо закріплені чіткі правила, умови та порядок отримання громадянами та інституційними структурами суспільства інформації в органах державної влади і місцевого самоврядування, від інших державних і недержавних юридичних осіб, а також прямого доступу до державних і недержавних інформаційних ресурсів. Як зазначає Гуцалюк М., органи (служби) інфрормаційної безпеки можуть створюватися (на законодавчих засадах) і в недержавних структурах для захисту своїх потреб в забезпеченні необхідною інформацією. Дані органи на основі укладення відповідних угод можуть бути приєднані до єдиної державної системи інформаційної безпеки. На теперішній час окремі елементи системи інформаційної безпеки створені та фрункціонують (органи зовнішньої розвідки, інформаційні служби різноманітних міністерств, система технічного та криптографічного захисту інформації держави і т. н.). Проте для їхнього функціонування ще недостатня правова база. Зміст діяльності органів інформаційної безпеки також ще не в повній мірі відповідає покладеним на них завданням. Це пояснюється в першу чергу недостатнім опрацюванням питань, що стосуються фрорм і способів забезпечення інформаційної безпеки [12].

Для ефективної реалізації державної політики, щодо побудови відкритого правового інформаційного простору України потрібно виконати ряд головних вимог. Більшість дослідників одностайні щодо переліку таких вимог. Так, наприклад А. Ф. Грицик зазначає:

1) в системі органів державної влади має бути сформована єдина структура, функцією якої є проведення державної інформаційної політики. Ця структура повинна охоплювати всі гілки і рівні державної влади і включати як спеціалізовані органи влади, що забезпечують регулювання інформаційної сфери, так і підрозділу в інших органах влади, відповідальні за інформаційні аспекти діяльності в сорері їх компетенції;

2) державне управління інформаційною сферою має бути планомірно забезпечене фінансовими і матеріальними ресурсами за рахунок бюджетного фінансування - природно, виходячи 3 реальних можливостей держави за статтею витрат на державне управління;

3) проведення державної інформаційної політики має координуватися з єдиного центру на рівні вищого керівництва країни при персональній відповідальності одного з вищих посадових осіб держави за вирішення цього завдання. Адже право вільно виражати думки та збирати, отримувати і поширювати інформацію, як і кожне право має свої обмеження [13].

Співіснування влади і суспільства в контексті соціальної історії визначається взаємозв'язком, в результаті якого суспільство фрормує відповідну часу владу, а вона, посилаючись на реалізацію національних інтересів, мусить контролювати суспільство. Одним з найважливіших елементів управління суспільством є державний контроль над інформацією. Система контролю і дозування інформації існує в кожній державі [14]. Але головне питання, яке так чи інакше постає в цьому контексті: в чиїх інтересах здійснюється такий контроль.

Висновки. На жаль, в даний час не тільки жодна з перелічених вище вимог у повному обсязі не виконується, але і на рівні вищого українського керівництва проведення цілеспрямованої інформаційної політики не розглядається в ряду першочергових завдань державного управління. Подібне неадекватне ставлення до створення відкритого і контрольованого інформаційного простору призводить до негативних наслідків, істотно відображаючись на розвитку України. Варто зауважити, що таке ставлення державної влади до інформаційної політики не тільки призвело до інформаційної війни, в стані якої перебуває Україна, а й створило можливості для успішної реалізації Росією інших елементів гібридної війни.

\section{Література}

1. Соснін, Олександр. Інформаційна сфера в реалізації інтересів інноваційного розвитку нації / Олександр Соснін // Віче. - 2011. - № 15/16. - С. 17-21

2. Милль, Дж. О свободе / Дж. Милль ; пер. с англ. А. Н. Неведомского // О свободе. Антология мировой либеральной мысли (I половины XX века). - М. : Прогресс-Традиция, 2000. - С. 288-392.

3. Моисеев, Н. Н. Расставание с простотой / Н. Н. Моисеев. - М. : АГРАФ, 1998. - С. 469

4. Антіпова, О. Філософсько-аксіологічні проблеми свободи слова в українському інформаційному просторі / О. Антіпова // Гілея: науковий вісник. - 2013. - № 74. - С. 207-209. 
5. Ракитов, А. И. Философия компьютерной революции / А. И. Ракитов. - М.: Политиздат, 1991. - С.32

6. Головій, В. М. Механізми взаємодії влади та ЗМІ в контексті становлення громадянського суспільства в Україні: автореф. дис... канд. наук з держ. упр.: 25.00.02 / В.М. Головій ; Класич. приват. ун-т. - Запоріжжя, 2009. - 20 с.

7. Петрова, Н. Медіа-право для студентів факультетів/відділень журналістики / Н. Петрова, В. Якубенко. - Київ, ТОВ «Київська типографія», 2007. - 280 с.

8. Яковенко, М. Інформаційний простір: фрілософські аспекти формування поняття / М. Яковенко // Вісник Національного університету «Львівська політехніка». - 2011. - № 692. - С. 22-27.

9. Войцих, Н. Державна політика в українському інформаційному просторі: стан та проблеми / Н. Войцих // Міжнародна інформація та міжнародні відносини. - 2013. - Вип. 2. - С. 6-12.

10. Мошковська, С. І. Передумови входження України у глобальний інформаційний простір в контексті вимог міжнародної інформаційної безпеки / С. І. Мошковська // Україна в системі глобального інформаційного обміну: теоретико-методологічні аспекти дослідження і підготовки фахівців : всеукраїнська наукова конференція, Львів, 27 травня 2011 р. - Львів : Видавництво Національного університету “Львівська політехніка", 2011. - С. 118-122.

11. Олійник, О. В. Політико- правові аспекти формування інформаційного суспільства суверенної і незалежної держави [Електронний ресурс] / О. В. Олійник, О. В. Соснін, Л. Є. Шиманський. - Режим доступу: http://www.niss. gov.ua/book/Sosnin2.html.

12. Гуцалюк, М. Інформаційна безпека України : нові загрози / М. Гуцалюк // Бизнес и безопасность. - 2003. - № 5. - С. 2-3

13. Грицик, А. Ф. Правова відповідальність за зловживання свободою інформації / А.Ф. Грицик // Україна в системі глобального інформаційного обміну: теоретико-методологічні аспекти дослідження і підготовки фрахівців : всеукраїнська наукова конференція, Львів, 27 травня 2011 р. - Львів : Видавництво Національного університету “Львівська політехніка", 2011. - С. 209-215.

14. Україна: політична історія. XX - початок XXI століття. - К. : Парламентське видавництво, 2007. - 1028 с.

\section{References}

1. Sosnin, O. (2011). Informatsiina sfera v realizatsii interesiv innovatsiinoho rozvytku natsii [Information sphere in realization of interests of innovative development of the nation]. Viche - Veche, 15/16, 17-21 [in Ukrainian].

2. Mill, J. (2000). O svobode [On Liberty]. (A. N. Nevedomskiy, Trans). Antologiya mirovoy liberalnoy mysli (I poloviny XX veka) - Anthology of world liberal thought (The first half of the twentieth century). (pp. 288-392). Moscow: Progress-Traditsiya [in Russian].

3. Moyseev, N. N. (1998). Rasstavanye s prostotoi [Parting with simplicity]. Moscow: AHRAF [in Russian].

4. Antipova, O. (2013). Filosofsko-aksiolohichni problemy svobody slova v ukrainskomu informatsiinomu prostori [Philosophical-axiological problems of freedom of speech in the Ukrainian information space]. Hileia - Gilea, 74, 207-209 [in Ukrainian].

5. Rakitov, A. I. (1991). Filosofiya kompyuternoy revolyutsii [The philosophy of the computer revolution]. Moscow: Politizdat [in Russian].

6. Holovii, V. M. (2009). Mekhanizmy vzaiemodii vlady ta ZMI v konteksti stanovlennia hromadianskoho suspilstva v Ukraini [Mechanisms of interaction between the authorities and the media in the context of civil society formation in Ukraine]. Extended abstract of candidate's thesis. Zaporizhzhia: KPU [in Ukrainian].

7. Petrova, N., Yakubenko, V. (2007). Media-pravo dlia studentiv fakultetiv/viddilen zhurnalistyky [Media law for students of faculties/departments of journalism]. Kyiv: TOV «Kyivska typohrafiia» [in Ukrainian].

8. Yakovenko, M. (2011). Informatsiinyi prostir: filosofski aspekty formuvannia poniattia [Information space: philosophical aspects of the concept formation]. Visnyk Natsionalnoho universytetu «Lvivska politekhnika» (Filosofski nauky) - Bulletin of the National University "Lviv Polytechnic" (Philosophical Sciences), 692, 22-27 [in Ukrainian].

9. Voitsykh, N. (2013). Derzhavna polityka v ukrainskomu informatsiinomu prostori: stan ta problemy [State policy in the Ukrainian information space: state and problems]. Mizhnarodna informatsiia ta mizhnarodni vidnosyny - International information and international relations, 2, 6-12 [in Ukrainian].

10. Moshkovska, S. I. (2011). Peredumovy vkhodzhennia Ukrainy u hlobalnyi informatsiinyi prostir $v$ konteksti vymoh mizhnarodnoi informatsiinoi bezpeky [Prerequisites of Ukraine's entry into the global information space in the context of the requirements of international information security]. Ukraina $v$ systemi hlobalnoho informatsiinoho obminu: teoretykometodolohichni aspekty doslidzhennia i pidhotovky fakhivtsiv - Ukraine in the system of global information exchange: theoretical and methodological aspects of research and training of specialists: All-Ukrainian scientific conference. (pp. 118-122). Lviv: Vydavnytstvo Natsionalnoho universytetu "Lvivska politekhnika" [in Ukrainian].

11. Oliinyk, O. V., Sosnin, O. V., Shymanskyi, L. Ye. (2001). Polityko-pravovi aspekty formuvannia informatsiinoho suspilstva suverennoi i nezalezhnoi derzhavy [Political and legal aspects of the formation of an information society of a sovereign and independent state]. Derzhava i pravo - State and Law, 13, 534-541 [in Ukrainian].

12. Hutsaliuk, M. (2003). Informatsiina bezpeka Ukrainy: novi zahrozy [Information Security of Ukraine: New Threats]. Byznes y bezopasnost - Business and Security, 5, 2-3 [in Ukrainian].

13. Hrytsyk, A. F. (2011). Pravova vidpovidalnist za zlovzhyvannia svobodoiu informatsii [Legal liability for abuse of information freedom]. Ukraina $v$ systemi hlobalnoho informatsiinoho obminu: teoretyko-metodolohichni aspekty doslidzhennia $i$ pidhotovky fakhivtsiv - Ukraine in the system of global information exchange: theoretical and methodological aspects of research and training of specialists: All-Ukrainian scientific conference. (pp. 209-215). Lviv: Vydavnytstvo Natsionalnoho universytetu "Lvivska politekhnika" [in Ukrainian].

14. Ukraina: politychna istoriia. XX - pochatok XXI stolittia [Ukraine: Political History. XX - beginning of XXI century]. (2007). Kyiv: Parlamentske vydavnytstvo [in Ukrainian].

Надійшла 29.10.2018

Бібліографічний опис для цитування :

Захаренко, К. В. Відкритість інформаційного простору та контроль за доступністю інформації / К. В. Захаренко // Проблеми соціальної роботи: філософія, психологія, соціологія. - 2018. - № 2 (12). - С. 30-35. 